Jurnal Teknologi, 48(E) Jun 2008: 15-31

(C) Universiti Teknologi Malaysia

\title{
KESAN LATIHAN PERGURUAN KE ATAS FAKTOR PEMILIHAN PERGURUAN
}

\author{
MOHAMED NAJIB ABDUL GHAFAR ${ }^{1} \&$ M. NOOR ARIFFIN ${ }^{2}$
}

\begin{abstract}
Abstrak. Kajian ini bertujuan untuk meninjau faktor-faktor pemilihan profesion perguruan dan kaitan dengan tahun pengajian pelajar Fakulti Pendidikan, Universiti Teknologi Malaysia. Kajian ini melibatkan 221 orang sampel dari pelajar tahun 1 dan tahun 4 yang mengikuti kursus pendidikan di sini. Instrumen yang digunakan adalah set soal selidik untuk menjawab persoalan kajian yang dikaji oleh penyelidik. Data telah diproses menggunakan perisian Statistical Package for Social Science (SPSS) versi 11.5 untuk mendapatkan nilai min, peratusan dan kekerapan kajian. Hasil dapatan kajian menunjukkan nilai min keseluruhan bagi setiap faktor-faktor pemilihan profesion perguruan, iaitu prestij (4.00) minat (3.76), ganjaran (3.58), persekitaran kerja (3.59) dan faktor yang paling rendah ialah faktor pengaruh (3.09). Kajian mendapati hanya satu faktor sahaja yang meningkat, iaitu faktor pengaruh, faktor prestij tidak berubah dan faktor minat, persekitaran kerja dan pengaruh menunjukkan penurunan setelah mendapat kursus pendidikan di sini. Di akhir kajian ini, pengkaji telah mengemukakan beberapa cadangan kepada pihak-pihak terbabit agar dapat mengambil langkah-langkah menangani masalah yang timbul hasil daripada kajian ini. Diharapkan kajian ini dapat menjadi sumber rujukan kepada para pelajar dan pihak-pihak berkenaan.
\end{abstract}

Kata kunci: Faktor pemilihan perguruan; kesan latihan; soal selidik

\subsection{PENGENALAN}

Pendidikan adalah satu proses yang amat penting dalam penyambungan atau penerusan dalam mana-mana masyarakat. Proses ini digunakan sebagai alat oleh sesebuah masyarakat itu dengan matlamat yang berbeza. Kepada pemerintah dan perancang, pendidikan adalah sebuah institusi yang menyediakan guna tenaga kepada negara. Warga pendidik melihat pendidikan sebagai proses yang menggerakkan pertumbuhan secara menyeluruh ke tahap maksimum seseorang individu sesuai dengan keupayaan semulajadi yang ada pada individu itu masing-masing.

Pendidikan merupakan elemen penting yang harus diutamakan dalam kehidupan seharian. Di Malaysia, bagi menghasilkan sebuah negara yang maju dan mempunyai taraf pendidikan yang tinggi, tindakan yang sewajarnya harus diberi perhatian. Pendidikan formal bermula dari sekolah rendah ke sekolah menengah dan guru memainkan peranan penting dalam proses penyampaian ilmu dan sebagai agen perantara ilmu. Selain itu, guru adalah model yang baik kepada pelajar, guru

$\overline{1 \& 2}$ Fakulti Pendidikan, Universiti Teknologi Malaysia, 81310 UTM Skudai, Johor Bahru, Malaysia Email: p-najib@utm.my 
seharusnya mempunyai sahsiah yang baik. Bersesuaian dengan pendapat Norlia (1999) perguruan ialah satu kerjaya yang bermatlamat untuk pembentukan insan dan ihsan yang sempurna agar manusia itu mengerti tentang peranan dan tanggungjawab mereka terhadap diri, masyarakat, alam yang mereka diami serta terhadap Keagungan Yang Maha Pencipta.

Dalam hal ini Mohd Kamal (1988) menjelaskan contoh teladan para pendidik inilah yang banyak membantu pembentukan akhlak pelajar. Merekalah yang seharusnya terlebih dahulu dilengkapi dengan ciri-ciri akhlak yang mulia walaupun masyarakat kurang menghargai watak-watak yang berbudi luhur. Ianya selaras dengan intipati falsafah pendidikan negara, iaitu pendidikan merupakan suatu usaha yang berterusan untuk memperkembangkan potensi individu secara menyeluruh dan bersepadu untuk melahirkan insan yang seimbang dan harmonis dari segi intelek, rohani, emosi dan jasmani berdasarkan kepercayaan dan kepatuhan kepada Tuhan.

Menurut Mohd Hanafiah (2001), dahulu peranan utama guru ialah penyampai pengetahuan, gurulah yang banyak bercakap dan menyoal. Kini peranan guru lebih penting sebagai pemudah cara dalam proses pembelajaran. Sebagai pemudah cara, guru perlu lebih sedia dan peka mewujudkan dan menggunakan situasi-situasi pembelajaran secara cekap dan berkesan. Murid perlu digerak supaya berfikir secara kreatif dan kritikal. Malahan murid dijangka dapat menyoal guru serta membantu guru membuka luas pintu pembelajarannya.

Persoalannya, sejauh manakah persediaan seorang guru untuk menghadapi cabaran murid yang mempunyai minda yang kreatif pada masa sekarang. Bagi menghadapi situasi sebegini, seseorang individu yang ingin menjadikan dirinya sebagai pendidik yang berjaya seharusnya mempunyai minat yang mendalam dalam bidang perguruan, kerana bidang ini memerlukan seseorang yang mempunyai keazaman yang tinggi bagi melahirkan pelajar yang berkualiti dan cemerlang.

Bidang perguruan merupakan satu profesion yang mempunyai tanggungjawab serta cabaran yang besar. Seseorang yang menceburkan diri dalam profesion perguruan, dengan rasminya mereka hendaklah bertanggungjawab dan menjaga nama baik profesion dengan mengamalkan profesionalisme perguruan semasa menjalankan tugasnya. Bagi memastikan bakal guru atau guru yang masih dalam perkhidmatan memberi khidmat yang cemerlang dan berkualiti, mereka haruslah mematuhi dan mengamalkan etika-etika yang telah digariskan oleh Kementerian Pendidikan.

\subsection{LATAR BELAKANG MASALAH}

Di Malaysia, jumlah guru semakin meningkat dari semasa ke semasa. Bidang pendidikan termasuk perguruan adalah suatu bidang yang penting yang mendapat perhatian khusus oleh kerajaan. Seorang guru perlu berjiwa pendidik dan bukan memilih perguruan sebagai bidang terakhir (Atan, 1984). Seseorang individu tidak seharusnya memilih profesion perguruan kerana tidak dapat memperoleh pekerjaan 
yang dikehendaki dan sebagai alternatif lain mereka memilih profesion perguruan. Dalam bidang perguruan, seorang guru haruslah mempunyai minat yang mendalam dalam profesionnya, ini kerana mereka merupakan orang yang bertanggungjawab untuk menyampaikan ilmu dan membentuk peribadi murid-muridnya. Fakta ini disokong oleh Garrison (1965). Seorang remaja yang mempunyai minat yang tinggi terhadap sesuatu subjek itu akan mencapai matlamat kerjaya mereka. Menjadi seorang guru haruslah mempunyai minat yang tinggi dalam bidang ini, kerana seorang guru harus memenuhi ciri-ciri profesion tersebut. Menurut Ghazali (1992), ahli profesional perlu mempunyai nilai moral yang tinggi, sikap positif dan etika profesional. Ini kerana 'survival' dan kemajuan negara bergantung kepada mereka.

Seseorang guru harus memenuhi etika perguruan untuk menjadi guru yang dapat menghasilkan keberkesanan dalam proses pengajaran dan pembelajaran. Tanpa minat yang mendalam, pelaksanaan kod etika perguruan ini sukar untuk dipenuhi. Etika Perguruan telah digubal dalam tahun 1970-an semasa Skim Gaji Aziz diperkenalkan bagi kakitangan kerajaan. Etika perguruan adalah satu set tingkah laku atau tanggung jawab guru terhadap masyarakat dan negara, terhadap pelajar, terhadap rakan sejawat dan terhadap ibu bapa. Oleh itu, setiap guru hendaklah menjalankan tugas tanpa melanggar etika ini.

Kerjaya guru tidak lagi menjadi pilihan utama atau status yang tinggi. Cuma sebilangan kecil sahaja yang benar-benar berminat dalam bidang pendidikan (Dewan Masyarakat, Januari 2004). Menurut kajian Kidder (1990), telah berlaku kemerosotan persepsi masyarakat terhadap guru sepuluh tahun kebelakangan ini adalah berpunca dari pengamalan etika dalam pendidikan guru yang semakin luntur dan telah berlaku fenomena yang negatif terhadap tanggapan tentang dunia perguruan di mana profesion perguruan dianggap remeh akibat segelintir guru-guru yang tidak menjalankan tugas dengan baik.

Menurut Zainun (1994) peranan guru sebagai profesional adalah semakin mencabar dan untuk menjadi seorang guru yang unggul, mereka perlu memiliki kebolehan akademik dan profesional secukupnya untuk melaksanakan tugas mereka dengan berkesan. Profesion perguruan ini memerlukan individu yang efisien dan berketerampilan dalam menghadapi era pendidikan yang global. Ianya adalah disebabkan oleh perkembangan informasi dan teknologi negara. Esah (2002) menerangkan guru sebagai seorang yang profesional dan kerjayanya seharusnya tidak mengutamakan gaji tetapi mengutamakan tanggungjawab terhadap pelajar dan masyarakat. Ini tidak bermakna gaji tidak penting kepada guru malah gaji yang tinggi dapat meningkatkan motivasi guru untuk meningkatkan prestasi mereka dalam profesionnya.

Teori Kerjaya Happockk (1976) menyatakan bahawa seseorang memilih pekerjaan adalah untuk memenuhi keperluan emosi dan nilai-nilai khas. Minat dan motivasi mempunyai hubungan rapat mengapa seseorang remaja membuat pemilihan kerjaya. Faktor pemilihan profesion ini amat penting untuk memastikan pelajar-pelajar yang mengikuti program-program pendidikan di institusi pengajian tinggi mendapat kursus 
yang betul-betul mereka minati atau hanya meneruskan pelajaran kerana ingin meneruskan pelajaran ke peringkat yang lebih tinggi.

Ternyata faktor minat dalam memilih pekerjaan telah dibuktikan oleh kajian yang telah dibuat oleh Walker (1990). Kajian itu menyatakan sebahagian besar daripada mereka yang berjaya dalam kerjaya memilih kerjaya berdasarkan minat dan bukan dari pendapatan yang diperolehnya. Selain daripada itu, adakah pembabitan dalam bidang tersebut dalam satu jangka masa tertentu akan mengubah faktor-faktor seseorang itu memilih kerjaya tersebut. Minat mungkin boleh berubah mengikut masa dan persekitaran di sekeliling. Di sesebuah institusi pengajian, minat mungkin boleh berubah dengan pendedahan yang diikuti dalam kursus yang diambil. Dalam kajian ini, pengkaji ingin melihat sama ada perubahan minat berlaku ataupun tidak semasa mengikuti program pengajian di sini selain dari faktor-faktor lain yang mempengaruhi pemilihan profesion perguruan.

\subsection{PENYATAAN MASALAH KAJIAN}

Tujuan penyelidik menjalankan kajian ini adalah untuk mengetahui faktor-faktor yang mendorong pelajar-pelajar Fakulti Pendidikan di Universiti Teknologi Malaysia memilih profesion perguruan dan kaitannya dengan tahun pengajian. Beberapa objektif telah ditetapkan, iaitu mengenal pasti faktor-faktor pemilihan profesion perguruan dan menerangkan perbezaan faktor pemilihan profesion perguruan antara pelajar tahun 1 dan tahun 4 .

Kajian ini bertujuan untuk melihat faktor-faktor yang mendorong pelajar di Fakulti Pendidikan Universiti Teknologi Malaysia yang memilih profesion guru. Faktor prestij, minat, ganjaran, persekitaran kerja dan pengaruh difokuskan dalam kajian ini. Hasil kajian boleh diberi perhatian oleh pihak yang berkenaan membuat tindakan yang sepatutnya bagi memastikan profesion perguruan ini diterajui oleh mereka yang sesuai dan berkebolehan dalam bidang tersebut. Ia juga dapat membuka minda para guru bahawa tanggungjawab guru merupakan satu tanggungjawab yang besar dan memberikan implikasi sepanjang hayat.

Menurut Sufean (1995), profesionalisme membawa maksud satu nilai yang berkait rapat dengan fungsi pekerjaan seseorang. Nilai ini perlu wujud dalam diri seseorang yang matlamat pekerjaannya untuk mencapai keberkesanan, produktiviti, kecekapan dan bertanggungjawab. Profesion perguruan pula membawa maksud satu profesion bermatlamatkan insan dan ihsan manusia yang sempurna agar manusia faham tentang peranan dan tanggungjawab mereka terhadap diri sendiri, masyarakat dan yang mereka didik serta terhadap Keesaan Yang Maha Pencipta (Sufean, 1993).

\subsection{METODOLOGI KAJIAN}

Kajian ini adalah berbentuk kajian deskriptif yang menggunakan pendekatan tinjauan. Pengkaji menggunakan set borang soal selidik sebagai instrumen bagi memudahkan perlaksanaan kajian. Sampel kajian dipilih secara rawak berstruktur. 
Instrumen yang digunakan bagi melaksanakan kajian ini adalah satu set borang soal selidik terdiri daripada 2 bahagian, iaitu Bahagian A mengenai latar belakang responden termasuklah umur, jantina, tahun dan kursus yang diambil oleh responden. Bahagian B pula adalah mengenai faktor-faktor yang mendorong pelajar memilih profesion perguruan sebagai kerjaya mereka pada masa akan datang (rujuk Jadual 1) berdasarkan faktor-faktor yang dikemukakan oleh Mohamad Najib (2004).

Jadual 1 Jadual penentuan ujian instrumen kajian

\begin{tabular}{lcc}
\hline Faktor Pendorong & No. Item & Bil. Item \\
\hline 1. Faktor Prestij & $1,6,11,16,21,26$ & 6 \\
2. Faktor Minat & $2,7,12,17,22,27$ & 6 \\
3. Faktor Ganjaran & $3,8,13,18,23,28$ & 6 \\
4. Faktor Persekitaran Kerja & $4,9,14,19,24,29$ & 6 \\
5. Faktor Pengaruh & $5,10,15,20,25,30$ & 6 \\
Jumlah bilangan item: & & $\mathbf{3 0}$ \\
\hline
\end{tabular}

\subsection{DAPATAN KAJIAN}

Berikut adalah dapatan kajian yang menunjukkan perbezaan faktor pemilihan profesion perguruan antara pelajar tahun 1 dan tahun 4 berdasarkan lima faktor. Pertama, Jadual 2 menunjukkan taburan responden tahun 1dan tahun 4 yang memilih profesion perguruan berdasarkan faktor prestij. Dalam item pertama berkaitan dengan faktor prestij menunjukkan nilai min pelajar tahun 1 bernilai 4.9 dan pelajar tahun 4 sebanyak 4.7. Ini menunjukkan perbezaan sebanyak 0.3 dalam item tentang penyataan bidang perguruan adalah pekerjaan yang mulia. Bagi item pekerjaan guru disanjung masyarakat, pelajar tahun 4 dengan nilai min 4.3 manakala pelajar tahun 1 sebanyak 4.6. Perbezaannya sebanyak 0.3. Menjadi guru membolehkan kita mendapat ramai kenalan pula menunjukkan perbezaan min sebanyak 0.2. Di mana pelajar tahun 1 dengan nilai 3.6 dan pelajar tahun 4 sebanyak 3.4.

Dapatan yang diperoleh dari kenyataan yang menyatakan guru adalah kerjaya yang penting kepada masyarakat. Nilai min pelajar tahun 1 lebih tinggi berbanding

Jadual 2 Taburan responden mengikut tahun pengajian berdasarkan faktor prestij

\begin{tabular}{clcc}
\hline Bil. & Item & Min tahun 1 & Min tahun 4 \\
\hline 1 & Bidang perguruan adalah pekerjaan yang mulia & 4.9 & 4.7 \\
2 & Pekerjaan guru disanjung masyarakat & 4.6 & 4.3 \\
3 & Jadi guru saya boleh mendapat ramai kenalan & 3.6 & 3.4 \\
4 & Guru adalah kerjaya yang strategik kepada masyarakat & 4.2 & 3.9 \\
5 & Masyarakat dapat menerima pandangan guru. & 3.8 & 3.8 \\
6 & Taraf hidup guru sesuai dengan masyarakat sekarang & 3.6 & 3.8 \\
\hline
\end{tabular}


pelajar tahun 4, iaitu 4.2. Pelajar tahun 4 pula bernilai 3.9. Jurang perbezaan antara pelajar tahun 1 dan tahun 4 adalah sebanyak 0.3. Masyarakat dapat menerima pandangan guru menunjukkan pelajar tahun 1 dan tahun 4 sependapat di mana nilai min yang diperoleh sama, iaitu 3.8. Bagi item terakhir dalam faktor prestij ini menyatakan taraf hidup guru sesuai dengan masyarakat sekarang, nilai min menunjukkan 3.6 pelajar tahun 1 dan 3.8 pelajar tahun 4. Perbezaannya sebanyak 0.2 peratus. Min keseluruhan bagi faktor prestij menunjukkan nilai min yang sama bagi pelajar tahun 1 dan tahun 4 dengan purata nilai min berangka 4.0.

Jadual 3 menunjukkan taburan responden tahun 1 dan 4 yang memilih profesion perguruan berdasarkan faktor minat. Dapatan kajian untuk melihat perbezaan tahun pengajian menunjukkan nilai min 3.6 bagi pelajar tahun 1 berbanding pelajar tahun 4 bernilai 3.5. Perbezaan menunjukkan 0.1 pelajar tahun 1 lebih ramai berbanding pelajar tahun 4 yang menyatakan mereka memang berminat untuk mengajar sejak kecil lagi. Perbezaan nilai min 0.1 juga terjadi dalam item yang menyatakan minat dalam bidang perguruan. Di mana pelajar tahun 1 melebihi pelajar tahun 4, iaitu sejumlah 4.1 dan 4.0. Nilai 4.4 bagi pelajar tahun 1 menyatakan mereka suka berkhidmat kepada masyarakat, pelajar tahun 4 pula bernilai 4.1 menunjukkan perbezaan sebanyak 0.3 .

Pendapat pelajar tahun 1 dan tahun 4 sama dalam item yang menyatakan peluang untuk melanjutkan pelajaran jika menjadi guru senang diperoleh dengan nilai min bernilai 3.6. Nilai min 3.4 bagi pelajar tahun 1 dan 3.5 bagi pelajar tahun 4 menyatakan bahawa menjadi guru, mereka akan berpeluang untuk menjadi guru bidang. Jurang perbezaan tersebut bernilai 0.1 memihak kepada pelajar tahun 4 . Guru sentiasa mengikuti perkembangan teknologi semasa menunjukkan nilai min pelajar tahun 4 melebihi pelajar tahun 1 sebanyak 0.1, iaitu 3.8 berbanding pelajar tahun 1 dengan nilai 3.7. Dalam faktor minat dalam pemilihan profesion perguruan menunjukkan pelajar tahun 1 mempunyai minat yang lebih tinggi berbanding pelajar tahun 4 . ini menunjukkan minat pelajar semakin berkurang selepas mengikuti program perguruan di Universiti Teknologi Malaysia. Nilai min purata bagi faktor minat menunjukkan pelajar tahun 1 dengan nilai 3.8 mengatasi pelajar tahun 4 sebanyak 0.1 dengan nilai min pelajar tahun 4 sebanyak 3.7

Jadual 3 Taburan responden mengikut tahun pengajian berdasarkan faktor minat

\begin{tabular}{clcc}
\hline Bil. & Item & Min tahun 1 & Min tahun 4 \\
\hline 1 & Saya memang suka mengajar sejak kecil lagi & 3.6 & 3.5 \\
2 & Saya meminati bidangperguruan & 4.1 & 4.0 \\
3 & Saya suka berkhidmat kepada masyarakat & 4.4 & 4.1 \\
4 & Peluang melanjutkan pelajaran senang diperoleh bila & & \\
& menjadi guru & 3.6 & 3.6 \\
5 & Jadi guru saya berpeluang menjadi guru bidang & 3.4 & 3.5 \\
6 & Guru sentiasa mengikuti perkembangan teknologi & & 3.8 \\
& semasa & 3.7 & 3.8 \\
\hline
\end{tabular}


Jadual 4 menunjukkan taburan responden tahun 1 dan 4 yang memilih profesion perguruan berdasarkan faktor ganjaran. Dapatan menunjukkan nilai min pelajar tahun 1 kurang 0.1 berbanding pelajar tahun 4 yang menyatakan gaji seorang guru lumayan. Nilai min pelajar tahun 4 sebanyak 2.8 melebihi pelajar tahun 1 dengan 2.7. Bagi kenyataan berkaitan dengan beban guru sesuai dengan tugas, Nilai min 3.2 bagi pelajar tahun 1 dan 3.1 bagi pelajar tahun 4 . Nilai min menunjukkan pelajar tahun 1 lebih 0.1 berbanding dengan pelajar tahun 4 . Jumlah pelajar tahun 1 dan tahun 4 dalam pernyataan kerjaya guru adalah terjamin menunjukkan nilai min yang sama, iaitu 4.4. Manakala dengan nilai min 3.9, pelajar tahun 1 menyatakan pekerjaan guru mempunyai cuti yang banyak berbeza dengan pelajar tahun 4 sebanyak 0.3 lebih daripada pelajar tahun 1, iaitu 4.2.

Jadual 4 Taburan responden mengikut tahun pengajian berdasarkan faktor ganjaran

\begin{tabular}{clcc}
\hline Bil. & Item & Min tahun 1 & Min tahun 4 \\
\hline 1 & Gaji seorang guru lumayan & 2.7 & 2.8 \\
2 & Beban guru sesuai dengan tugas & 3.2 & 3.1 \\
3 & Kerjaya guru adalah terjamin & 4.4 & 4.4 \\
4 & Pekerjaan guru mempunyai cuti yang banyak & 3.9 & 4.2 \\
5 & Jadi guru memberi peluang untuk pergi melancong & 2.9 & 3.1 \\
6 & Saya suka bergaul dengan masyarakat & 4.2 & 3.9 \\
\hline
\end{tabular}

Nilai min 3.1 bagi pelajar tahun 4 menyatakan menjadi seorang guru akan memberi peluang untuk pergi melancong. Berbeza dengan pelajar tahun 1 dengan nilai 2.9. Perbezaan nilai min menunjukkan sebanyak 0.2 pelajar tahun 4 mengatasi pelajar tahun 1. Bagi item yang menyatakan bahawa mereka suka bergaul masyarakat, dapatan menunjukkan pelajar tahun 1 mendahului pelajar tahun 4. Nilai min menunjukkan sejumlah 4.2 untuk pelajar tahun 1 dan 3.9 pelajar tahun 4 yang menunjukkan perbezaan sebanyak 0.2 peratus. Min purata menunjukkan pelajar tahun 1 bernilai 3.5 berbanding pelajar tahun 4 dengan nilai min 3.7. Perbezaan min menunjukkan faktor ganjaran pelajar tahun 4 semakin bertambah 0.2 apabila responden mengikuti kursus perguruan.

Jadual 5 menunjukkan taburan responden mengikut tahun pengajian yang memilih profesion perguruan berdasarkan faktor persekitaran kerja. Dapatan yang diperoleh daripada responden tahun 1 dan tahun 4 berkaitan tentang profesion guru tidak terikat dengan masa menunjukkan pelajar tahun 1 kurang 0.1 daripada pelajar tahun 4, iaitu bernilai 2.7 berbanding pelajar tahun 4 bernilai 2.8. Bagi kenyataan yang menyatakan persekitaran kerja guru bersih, nilai min menunjukkan sejumlah 3.8 pelajar tahun 1 dan tahun 4 menyokong penyataan itu.

Min pelajar tahun 1 bernilai 4.1 mengatasi pelajar tahun 4 dengan nilai 3.9 tentang pernyataan tentang pekerjaan guru membolehkan mereka berkongsi pandangan 
dengan rakan sekerja. Sejumlah 0.2 perbezaan nilai min. Manakala bagi item tentang tidak suka terikat dengan peraturan, 4.2 min pelajar tahun 1 dan 3.5 min pelajar tahun 4. Nilai min menunjukkan sejumlah 0.3 pelajar tahun 1 kurang daripada pelajar tahun 4. Dalam faktor persekitaran kerja ini, 4.3 nilai min pelajar tahun 1 menyatakan bahawa mereka boleh mempraktikkan kemahiran yang ada manakala pelajar tahun 4 sebanyak 3.9 menunjukkan perbezaan min sebanyak 0.4 antara pelajar tahun 1 dan tahun 4 .

Bagi item yang seterusnya tentang membuat kerja sampingan jika ada masa terluang, pelajar tahun 1 berjumlah 3.9 mengatasi nilai min pelajar tahun 4 sebanyak 0.1, iaitu 3.8. Min purata menunjukkan pelajar tahun 1 lebih cenderung memilih profesion perguruan berdasarkan faktor persekitaran kerja dengan perbezaan nilai min sebanyak 0.1 Pelajar tahun 4 dengan nilai min bernilai 3.6 berbanding pelajar tahun 1 dengan nilai 3.7. Dapat disimpulkan, setelah menjalani latihan perguruan dan pendedahan lebih dekat tentang bidang perguruan, faktor persekitaran kerja tidak dapat meningkatkan semangat pelajar tahun 4 untuk terus memilih profesion.

Jadual 5 di atas menunjukkan taburan responden tahun 1 dan 4 yang memilih profesion perguruan berdasarkan faktor pengaruh. Kenyataan mengenai ibu bapa seorang guru menunjukkan nilai min pelajar tahun 1 sebanyak 1.8 manakala pelajar tahun 4 bernilai 1.9. Pelajar tahun 4 mengatasi pelajar tahun 1 dengan 0.1. Bagi item kedua dalam faktor pengaruh menyatakan ahli keluarga ramai yang terlibat dengan bidang perguruan, nilai min menunjukkan 0.2 pelajar tahun 1 mengatasi pelajar tahun 4. Nilai min 3.0 untuk pelajar tahun 1 dan 2.8 bagi pelajar tahun 4 . Nilai min pelajar tahun 1 menunjukkan 2.6 berbanding dengan pelajar tahun 4 dengan nilai 2.9. Ini menunjukkan perbezaan nilai min sebanyak 0.4 dalam pernyataan yang menyatakan menjadi guru membolehkan mereka tinggal dekat dengan keluarga. Bagi penyataan ramai rakan yang memilih profesion perguruan, 3.3 nilai min pelajar tahun 1 dan 3.0 bagi pelajar tahun 4 . Bermakna lebih ramai pelajar tahun 1 memilih profesion perguruan disebabkan rakan-rakan dengan perbezaan min sebanyak 0.3.

Jadual 5 Taburan responden mengikut tahun pengajian berdasarkan faktor persekitaran kerja

\begin{tabular}{|c|c|c|c|}
\hline Bil. & Item & Min tahun 1 & Min tahun 4 \\
\hline 1 & Guru tidak terikat dengan masa & 2.7 & 2.8 \\
\hline 2 & Persekitaran kerja yang bersih & 3.8 & 3.8 \\
\hline 3 & Jadi guru membolehkan saya berkongsi pandangan & & \\
\hline & dengan rakan sekerja & 4.1 & 3.9 \\
\hline 4 & Saya tidak suka terikat dengan peraturan & 3.2 & 3.5 \\
\hline 5 & $\begin{array}{l}\text { Guru membolehkan saya mempraktikkan kemahiran } \\
\text { yang ada }\end{array}$ & 4.3 & 3.9 \\
\hline 6 & $\begin{array}{l}\text { Saya boleh buat kerja sampingan jika ada masa } \\
\text { terluang }\end{array}$ & 3.9 & 3.8 \\
\hline
\end{tabular}


Jadual 6 Taburan responden mengikut tahun pengajian berdasarkan faktor pengaruh

\begin{tabular}{clcc}
\hline Bil. & Item & Min tahun 1 & Min tahun 4 \\
\hline $\mathbf{1}$ & Ibu dan bapa saya seorang guru & 1.8 & 1.9 \\
$\mathbf{2}$ & Ahli keluarga saya ramai bekerja sebagai guru & 3.0 & 2.8 \\
$\mathbf{3}$ & Jadi guru membolehkan saya tinggal dekat dengan & & \\
& keluarga & 2.6 & 2.9 \\
$\mathbf{4}$ & Ramai rakan saya yangmemilih profesion guru & 3.3 & 3.0 \\
$\mathbf{5}$ & Saya sukakan kanak-kanak & 4.3 & 3.9 \\
$\mathbf{6}$ & Bekas guru saya sumber inspirasi saya & 4.1 & 3.9 \\
\hline
\end{tabular}

Dapatan seterusnya ialah berkaitan suka kepada kanak-kanak, min bernilai 4.3 bagi pelajar tahun 1 dan 3.9 pelajar tahun 4. (Lihat Jadual 6) Perbezaan nilai min responden yang suka kepada kanak-kanak ialah 0.4 peratus. Manakala item seterusnya yang berkaitan guru sebagai inspirasi menunjukkan min pelajar tahun 1 berjumlah 4.1 dan pelajar tahun 4, berjumlah 3.9. Perbezaan sebanyak 0.2 nilai min pelajar tahun 1 dan tahun 4 menjadikan guru sebagai salah satu faktor mereka memilih profesion perguruan. Min purata bagi faktor pengaruh menyebabkan responden memilih profesion perguruan menunjukkan pelajar tahun 1 dengan nilai min purata sebanyak 3.2 dan pelajar tahun 4 dengan nilai 3.1. Perbezaan min menunjukkan 0.1 pelajar tahun 1 lebih berbanding pelajar tahun 4 . Setelah menjalani kursus perguruan selama 4 tahun, didapati faktor pengaruh semakin berkurang dalam diri pelajar berbanding di awal kursus ini.

\subsection{PERBINCANGAN}

Keputusan dibincang berasaskan lima faktor utama seseorang memilih profesion perguruan, diterangkan seperti berikut.

\subsection{Faktor Prestij}

Daripada dapatan keseluruhan yang diperoleh menunjukkan kebanyakan responden bersetuju menyatakan faktor prestij merupakan salah satu faktor yang mendorong mereka memilih profesion perguruan. Profesion perguruan melibatkan ilmu pengetahuan dan terikat dengan etika-etika yang bersesuaian dengan kehidupan masa sekarang. Guru pada pandangan masyarakat, merupakan seorang yang berpengaruh tinggi dan mempunyai ilmu yang tiada batasnya. Selaras dengan pendapat Mok Soon Sang (1995), pekerjaan guru adalah pekerjaan yang melibatkan intelek dan tindakan. Seorang guru itu perlu sentiasa berfikir, merancang dan menilai pelajar-pelajarnya dari sudut positif dan bersikap dedikasi. Untuk memiliki keupayaan akademik yang cemerlang, seorang guru perlu sentiasa berusaha untuk menerokai lebih dalam sesuatu ilmu pengetahuan sejajar dengan pertumbuhan ilmu yang sentiasa 
berkembang sebelum disampaikan kepada anak didiknya. Profesion perguruan semakin mendapat pengiktirafan masyarakat di atas usaha yang diberikan oleh guru kepada mereka. Pengiktirafan masyarakat kepada profesion guru akan menguatkan lagi semangat guru untuk berjuang dalam pendidikan walaupun pada zaman sekarang, profesion guru boleh dianggap mencabar dengan masalah sosial yang semakin meningkat. Selaras dengan pendapat Ginzberg (1995) penghormatan yang diterima dari orang sekeliling dan kemampuan untuk yakin pada keputusan diri akan memberikan satu pengalaman yang kuat terhadap tumpuan, imaginasi, usaha dan keinginan untuk terus melaksanakan sesuatu tugas.

Maklum balas yang positif ditunjukkan oleh responden menyatakan pekerjaan guru merupakan satu pekerjaan yang mulia. Sebagai seorang yang berilmu dan bertugas sebagai penyampainya, sudah tentu pekerjaan guru merupakan satu pekerjaan mulia di mata masyarakat dan agama. Manakala dapatan yang diperoleh daripada pelajar tahun 1 dan tahun 4 menunjukkan nilai min yang sama di mana responden menunjukkan nilai yang positif menyatakan mereka memilih profesion perguruan kerana faktor prestij. Seawal menjalani kursus perguruan di sini,kebanyakan responden menyatakan salah satu faktor pemilihan profesion mereka adalah disebabkan faktor prestij. Walau bagaimanapun, di akhir pengajian faktor prestij masih berada pada takuk lama, tanpa berlaku sebarang perubahan. Sepatutnya setelah mengikuti latihan perguruan, faktor prestij seharusnya meningkat kerana mereka telah didedahkan dengan lebih dekat dengan bidang ini.

\subsection{Faktor Minat}

Faktor minat kepada bidang perguruan, menunjukkan dapatan yang positif daripada responden. Minat memainkan peranan besar dalam pemilihan profesion kerana ia akan memberi impak yang besar dalam sesuatu pekerjaan. Dengan minat yang mendalam dalam bidang perguruan, seorang guru akan berusaha untuk melakukan yang terbaik dalam proses pengajaran dan pembelajaran. Ismail (1992) menyatakan minat terhadap sesuatu perkara atau aktiviti mendorong seseorang untuk meneroka dengan lebih jauh. Seseorang yang berminat dengan pekerjaan yang dilakukan akan memastikan kerja yang dilakukan sempurna dan dapat diterima oleh orang ramai. Begitu juga situasi bagi seorang guru, untuk memastikan proses pengajaran dan pembelajaran dapat diterima pelajar dengan baik, guru akan mempelbagaikan cara pengajaran mereka dan menggunakan segala kemudahan yang ada untuk memastikan hasil yang diperoleh adalah sempurna. Tajul (1996) menyatakan ciri-ciri penting yang perlu ada atau dimiliki oleh setiap guru mahupun bakal guru ialah minat yang penuh terhadap keseluruhan tugasnya baik di sekolah mahupun melibatkan warga luar sekolah.

Dapatan yang positif ditunjukkan oleh pelajar yang mengambil kursus pendidikan mengenai peluang melanjutkan pelajaran apabila memilih profesion guru. Ini jelas dapat dilihat di Universiti Teknologi Malaysia sendiri di mana guru-guru yang telah 
mengajar dengan kelulusan tertentu dapat menyambung pelajaran mereka ke peringkat yang lebih tinggi. Dalam kajian Gobi (1997), di mana 70.1\% responden mengakui bahawa profesion perguruan membuka peluang untuk melanjutkan pelajaran ke peringkat yang lebih tinggi. Oleh sebab itu, masih ada segelintir daripada masyarakat memilih profesion perguruan sebagai salah satu batu loncatan untuk menyambung pelajaran mereka ke peringkat yang lebih tinggi. Holland (1973) menyatakan faktor minat berkaitan dengan cita rasa individu tersendiri mengenai alam pekerjaan. Ia mempunyai nilai positif atau negatif yang tersendiri terhadap sesuatu bidang pekerjaan.Jadi tidak hairanlah sesetengah individu mengambil kursus perguruan sebagai salah satu cara untuk memperoleh ijazah dan membuka peluang kepada pekerjaan lain atau peluang melanjutkan pelajaran dalam bidang lain.

Dapatan menunjukkan pelajar tahun 4 semakin kurang berminat dengan bidang perguruan. Ini berdasarkan dapatan menunjukkan minat pelajar tahun 1 lebih tinggi berbanding pelajar tahun 4. Dapatan ini menunjukkan situasi yang tidak baik. Di mana setelah menjalani latihan perguruan sepatutnya minat kepada bidang perguruan semakin bertambah. Tetapi dapatan yang diperoleh adalah sebaliknya. Keadaan ini harus diambil serius oleh pihak fakulti pendidikan kerana produk yang dihasilkan tidak mempunyai minat yang tinggi dalam profesion perguruan. Pihak fakulti seharusnya menyemak kembali silibus yang dicadangkan kepada pelajar supaya ia dapat meningkatkan minat pelajar kepada profesion perguruan selain memastikan proses pengajaran dan pembelajaran yang berlaku dalam kelas yang lebih berkesan.

\subsection{Faktor Ganjaran}

Dapatan kajian ini menunjukkan nilai yang positif menyatakan faktor ganjaran merupakan salah satu faktor mereka memilih profesion perguruan. Ganjaran atau gaji, memainkan peranan penting dalam pemilihan profesion. Faktor ini boleh memberi motivasi kepada seseorang individu untuk memberi hasil yang terbaik dalam kerjayanya. Begitu juga bidang pendidikan, melalui sumber kewangan itulah para guru dapat memenuhi keperluan dan kehendak mereka. Ini bertepatan dengan tingkat keperluan Maslow yang menyatakan gaji dan ganjaran merupakan salah satu keperluan dalam kehidupan seseorang manusia. Dapatan kajian menunjukkan nilai min 2.8 yang menyatakan gaji guru lumayan. Bersesuaian dengan hasil kajian yang dibuat untuk Nasional Educational Association, Amerika Syarikat (Parkley, 1993) yang menunjukkan lebih 50\% guru melahirkan rasa tidak puas hati dengan gaji yang ditawarkan dalam profesion perguruan kerana terlalu rendah. Sebahagian besar responden berpendapat beban kerja guru tidak berpatutan dengan gaji yang ditawarkan. Tanggungjawab dan beban kerja guru pada masa sekarang semakin hari semakin bertambah dan mencabar. Pendapat ini selaras dengan kajian Gobi (1997) yang mana dapatan menunjukkan gaji guru tidak sesuai dengan beban kerja yang ditanggung oleh guru. Di mana $75.1 \%$ peratus responden tidak setuju menyatakan gaji guru sesuai dengan beban kerja. 
Dapatan daripada kajian ini menunjukkan pelajar tahun 4 menganggap ganjaran dalam bidang perguruan merupakan pendapatan yang lumayan berbanding pelajar tahun 1. Setelah menjalani kursus perguruan selama 4 tahun didapati responden semakin bertambah yakin bahawa gaji guru sesuai dengan beban kerja yang ditanggung oleh guru. Pendapat ini bertentangan dengan sesetengah dapatan yang diperoleh daripada kajian-kajian dan pendapat yang ada sebelum ini yang menyatakan gaji guru tidak setimpal dengan beban yang ditanggung oleh guru. Tetapi jika dilihat secara keseluruhan dalam faktor ganjaran ini, gaji merupakan aspek yang paling jelas bermain di fikiran responden. Ganjaran lain yang harus diambil kira dalam faktor ini seperti jangka masa kerja, cuti, jaminan profesion, dan pergaulan dengan masyarakat tidak seharusnya diabaikan.

\subsection{Faktor Persekitaran Kerja}

Dalam pemilihan profesion, persekitaran kerja amat penting untuk memastikan pekerjaan yang dilakukan berjalan dengan baik. Persekitaran kerja yang bersih menunjukkan dapatan yang positif bagi pekerjaan guru. Sebagai seorang guru, persekitaran yang bersih dan segar akan mewujudkan suasana pembelajaran yang kondusif dan sihat. Menurut Crow\&Crow (1980), sikap adalah hasil sampingan yang menjelaskan pengalaman seseorang individu mempunyai asasnya pada desakan dalaman, tabiat yang dipelajari dan pengaruh alam sekitar yang mengelilinginya. Selain daripada itu, seseorang guru haruslah mempunyai peribadi yang baik untuk mendidik anak bangsa mereka ke arah kebaikan agar dapat mewujudkan negara yang aman dan maju. Kenyataan ini selaras dengan pendapat Noran Fauziah dan Ahmad Mahdzan (1993) yang menyatakan bahawa guru merupakan golongan yang memberikan kesan yang amat besar terhadap personaliti, mental dan fizikal setiap insan yang dididiknya. Ini kerana guru bukan sahaja bertugas mengajar subjeksubjek tertentu tetapi juga mendidik dalam memberikan tunjuk ajar di samping teladan yang baik.

Daripada dapatan yang diperoleh, keseluruhannya, pelajar tahun 1 menunjukkan dapatan yang lebih tinggi berbanding pelajar tahun 4 tentang pendapat tentang pemilihan profesion perguruan disebabkan faktor persekitaran kerja. Sebagai pelajar yang telah mengikuti latihan perguruan di sini, mereka telah didedahkan dengan suasana pekerjaan guru yang sebenar. Mereka telah di hantar ke sekolah untuk mempraktikkan kemahiran yang telah mereka pelajari di sini. Setelah didedahkan dengan persekitaran kerja guru yang sebenar adakah menjadi penyebab faktor persekitaran kerja semakin menurun berlawanan dengan andaian awal tentang faktor persekitaran kerja ini.

\subsection{Faktor Pengaruh}

Hasil dapatan yang diperoleh daripada kajian menunjukkan salah satu faktor yang mempengaruhi responden memilih profesion perguruan adalah disebabkan faktor 
pengaruh. Kebanyakan responden memilih profesion perguruan kerana ramai di kalangan rakan-rakan mereka memilih profesion perguruan dan mereka suka kanakkanak, iaitu pelajar. Berdasarkan kajian yang telah dijalankan oleh Fieldman dan New Comb (1969), faktor utama yang mengubah sikap pelajar ialah hubungan dengan rakan sebaya. Rakan sebaya merupakan orang yang paling hampir dengan persekitaran pelajar, ini akan menyebabkan keinginan dan kesukaan terhadap sesuatu akan dipengaruhi oleh rakan-rakan sebaya mereka. Rakan sebaya merupakan insan yang berpengaruh dalam membentuk peribadi seseorang, ini kerana segala perkara yang dilakukan seharian di sekolah atau luar adalah sama dan mereka saling bekerjasama antara satu sama lain. Tidak hairanlah jika ramai responden memilih profesion perguruan kerana pengaruh rakan sebaya. Menurut Atan (1994), seseorang itu lebih cenderung untuk memilih rakan sebaya yang mempunyai minat yang sama. Cara hidup yang sama dapat membantu mencapai kejayaan individu kerana adanya kerjasama, perasaan bertimbang rasa dan saling memahami antara satu sama lain.

Reaksi negatif daripada responden menyatakan ibu bapa dan saudara mereka ramai yang memilih profesion perguruan menyebabkan mereka memilih profesion yang sama. Ibu bapa hanya perlu memastikan anak-anak mereka berusaha bersungguh-sungguh untuk mencapai impian dan minat mereka kepada sesuatu perkara. Menurut Griswold (1986), ibu bapa perlu melibatkan diri dalam semua aktiviti dan tidak terhad kepada aktiviti akademik sahaja untuk menggalakkan anakanaknya berjaya dalam pelajaran mereka. Tidak semestinya anak-anak harus mewarisi pekerjaan yang dilakukan oleh ibu bapa mereka, tugas ibu bapa hanya memberi dorongan dan sokongan kepada anak-anak mereka supaya berjaya dalam pelajaran dan memilih profesion yang mereka minat. Menurut Mohd Fadilah (1997), ibu bapa bukan sahaja bertindak sebagai penjaga, pendidik, pengasuh, pemimpin malah lebih daripada itu. Beliau telah mendalami lagi peranan ibu bapa juga kawan, pengikut, pendorong (motivasi) dan pembuka minda serta rangsangan. Tidak hairan jika ibu bapa boleh menjadi sumber rujukan dalam mendorong keputusan seseorang dalam memilih sesebuah kerjaya. Dalam proses pemilihan profesion perguruan, tidak semestinya ibu bapa bekerja sebagai guru boleh mendorong responden untuk memilih bidang perguruan. Tetapi ibu bapa boleh memberi tunjuk ajar dan merangsang anak-anak untuk memilih profesion yang mereka sukai.

Dapatan bagi penyataan menyatakan faktor pemilihan profesion perguruan disebabkan oleh guru sebagai sumber inspirasi menunjukkan nilai yang positif di kalangan pelajar. Perwatakan guru, cara pengajaran, pergaulan guru menunjukkan responden amat berminat untuk memilih profesion perguruan. Kajian oleh pengkaji akademik Benjamin Wright dan Shirley Tuska dalam Forrest dan Hardcastle (1990) terhadap 4500 orang guru pelatih mendapati ramai pelatih yang mengenang gurunya sebagai "admired" dan "influential." Ciri-ciri gurunya yang terdahulu memberikan inspirasi tertentu mengikut jejak gurunya menjadi pendidik (Gobi, 1997). Sebagai guru, kerektor mereka memainkan peranan besar bagi pelajar. Segala tingkahlaku 
yang ditunjukkan oleh guru akan menimbulkan rasa minat pelajar kepada bidang perguruan. Tidak hairan lebih ramai pelajar tahun 1 menyatakan mereka lebih terpengaruh dengan guru mereka menyebabkan mereka memilih profesion perguruan. Jika dibandingkan dengan pelajar tahun 4, setelah lama meninggalkan alam persekolahan, pengaruh guru tidak lagi menjadi faktor penting dalam pemilihan profesion mereka. Mengikut teori pemilihan kerjaya Holand (1973), sesuatu bidang yang menarik minat seseorang adalah berdasarkan latar belakang kehidupan dan personalitinya, maka pekerjaan itu juga boleh menarik minat individu lain yang mempunyai latar belakang yang sama.

\subsection{RUMUSAN}

Sebagai rumusan setelah menjalani latihan perguruan di UTM selama 4 tahun, didapati hanya faktor ganjaran yang menunjukkan sedikit peningkatan, manakala faktor prestij tidak berubah. Faktor lain, iaitu faktor minat, faktor persekitaran kerja dan faktor pengaruh menunjukkan sedikit penurunan. Sepatutnya, faktor-faktor yang dikaji dalam kajian ini menunjukkan peningkatan, tetapi hasil dapatan agak memeranjatkan di mana hanya faktor ganjaran sahaja yang menunjukkan peningkatan, manakala faktor lain berada pada tahap yang sama dan ada yang menurun. Dalam kajian ini,didapati faktor prestij tidak meningkat setelah menjalani kursus perguruan selama 4 tahun. Entah di mana silapnya, responden tidak dapat meningkatkan faktor prestij untuk meningkatkan motivasi dalam diri mereka. Walaupun tiada peningkatan yang berlaku, kebanyakan menyatakan faktor prestij merupakan salah satu faktor yang mendorong mereka memilih profesion perguruan. Cuma tiada perubahan yang berlaku dalam faktor prestij sepanjang responden menjalani latihan perguruan di sini.

Pelbagai cara telah dilakukan untuk menaikkan prestij perguruan antaranya menaikkan gaji guru selaras dengan pernyataan Tan Sri Ainuddin Wahid yang menyatakan cara menaikkan gaji para guru sehingga mengatasi gaji dalam profesion lain boleh membawa beberapa perubahan positif secara keseluruhannya (Dewan Masyarakat, Januari 2004). Daripada tindakan yang diambil oleh pihak Kementerian masih tidak mampu untuk menaikkan pengiktirafan responden sepanjang masa pengajian. Pengiktirafan merupakan faktor penting untuk memotivasikan seseorang dalam sesuatu pekerjaan. Walaupun jelas nilai prestij dalam bidang perguruan sangat tinggi pada masa sekarang, tetapi kejadian-kejadian yang mengaibkan warga guru, seperti guru telah ditangkap kerana mencabul kehormatan anak murid dan kes guru didakwa mendera anak murid hanya kerana kesalahan yang terlalu kecil jika di bandingkan dengan hukuman yang diberikan (Mingguan Malaysia, 27 Feb). Guru yang diharap membimbing dan mendidik telah menyalah gunakan kepercayaan yang diletakkan kepada mereka dengan melakukan perkara yang tidak sepatutnya dilakukan oleh seorang yang dihormati di mata masyarakat. Jadi tidak hairanlah walaupun prestij masih menjadi faktor kepada responden sebagai faktor pemilihan 
profesion mereka tetapi kejadian sebegini menyebabkan ia tidak menunjukkan peningkatan walaupun telah lama mengikuti kursus perguruan ini.

Faktor ganjaran merupakan satu-satunya faktor yang menunjukkan peningkatan dalam kajian ini. Responden yang telah melalui kursus perguruan dan telah menjalani latihan praktikal di sekolah semakin yakin dengan pemilihan profesion guru disebabkan faktor ganjaran. Jika dilihat secara keseluruhan dalam faktor ganjaran, gaji merupakan aspek yang paling jelas bermain di fikiran responden. Ganjaran lain yang harus diambil kira dalam faktor ini seperti jangka masa kerja, cuti, jaminan profesion, dan pergaulan dengan masyarakat tidak seharusnya diabaikan. Perkara ini menyerupai hasil kajian Goodlad (1984) apabila beliau mendapati graduan kejuruteraan yang memilih profesion perguruan sebagai pilihan pertama kerjaya mereka memberikan pangkat ketiga atas sebab "gaji baik" jaminan kerja yang berkaitan profesion perguruan termasuklah masa kerja yang pendek dan cuti yang panjang. Oleh sebab itu, responden tahun 4 lebih bersetuju dari responden tahun 1 menyatakan faktor ganjaran menyebabkan mereka memilih profesion perguruan kerana gaji yang diberikan adalah setimpal dengan ganjaran lain yang diperolehnya.

Perbincangan mengenai faktor minat menunjukkan dapatan yang agak mengejutkan, di mana setelah menjalani kursus perguruan, faktor minat semakin berkurang, mungkin kah kursus perguruan yang diikuti tidak dapat menambah malah semakin mengurangkan minat responden terhadap bidang perguruan. Menurut Burner (1960), cara yang terbaik untuk membina minat pelajar ialah dengan menerangkan tentang kepentingan mata pelajaran serta ilmu yang diperoleh pada masa-masa akan datang. Pelajar akan lebih berminat sekiranya mata pelajaran yang diajar mempunyai kaitan dengan alam pekerjaan yang bakal mereka tempuhi suatu masa nanti. Apabila pelajar mula mengetahui kegunaan pembelajaran dan pengalaman yang di timba dari program perguruan yang dianjurkan, minat mereka kepada bidang perguruan akan bertambah. Pendapat Sufean (1993) menyatakan minat merupakan keghairahan atau kegemaran seseorang untuk melakukan sesuatu perkara.

Faktor persekitaran kerja juga menunjukkan sedikit penurunan jika dibandingkan dengan pelajar tahun 1. Setelah 4 tahun menjalani latihan perguruan, responden telah didedahkan dengan latihan praktikal di mana mereka perlu ke sekolah untuk mempraktikkan segala kemahiran yang telah dipelajari. Sebelum menjalani latihan praktikal di sekolah kebanyakan responden bersetuju menyatakan faktor persekitaran kerja merupakan salah satu faktor penyebab mereka memilih profesion perguruan. Setelah mendapat kursus pendidikan hampir 4 tahun, faktor persekitaran kerja semakin berkurang. Adakah setelah didedahkan dengan persekitaran kerja sebagai guru praktikal, responden tidak mendapat gambaran yang baik tentang persekitaran kerja sebagai guru yang sebenar. Perkara ini disokong oleh Teori Kerjaya Happockk (1976) yang menyatakan bahawa seseorang memilih pekerjaan adalah untuk memenuhi keperluan emosi dan nilai-nilai khas. Mereka harus berupaya membuat 
jangkaan yang tepat, mempamerkan nilai yang tinggi dan melihat profesion perguruan dengan persepsi yang betul. Jangkaan yang tidak tepat dengan faktor persekitaran kerja dalam bidang perguruan menyebabkan berlaku sedikit penurunan faktor persekitaran kerja yang menyebabkan responden memilih profesion ini.

Faktor yang terakhir yang dikaji ialah faktor pengaruh juga didapati menurun jika dibandingkan dapatan pelajar tahun 1 dengan pelajar tahun 4. Daripada teori pemilihan kerjaya yang diutarakan oleh Holland (1973) menyatakan pemilihan kerjaya adalah perlakuan yang menggambarkan motivasi, pengetahuan dan kebolehan individu. Setelah mendapat pengetahuan tentang bidang perguruan sedikit sebanyak akan mengurangkan faktor pengaruh dalam pemilihan profesion seseorang. Ini jelas hasil daripada dapatan yang diperoleh daripada kajian ini menunjukkan faktor pengaruh semakin menurun setelah mendapat pendidikan tentang perguruan. Keyakinan yang tinggi terhadap kebolehan diri akan memadamkan faktor pengaruh sedikit demi sedikit apabila seseorang berasa seronok dengan bidang yang dipilihnya.

Minat pelajar semakin berkurang setelah mengikuti kursus perguruan selama 4 tahun. Untuk meningkatkan minat yang tinggi, pihak fakulti seharusnya mengkaji kembali silibus yang dicadangkan kepada pelajar agar latihan yang sempurna dan lengkap daripada semua aspek perguruan diberikan kepada calon. Teori dan praktikal perlulah seimbang agar apa yang dipelajari dapat digunakan selepas menamatkan pengajian nanti. Pihak Kementerian Pendidikan seharusnya berusaha untuk menaikkan imej dan status guru dengan memberi penekanan kepada aspek pengajaran dan pembelajaran yang lebih berkesan, budaya ilmu dan pembentukan sahsiah. Ini adalah supaya guru lebih bersedia menghadapi cabaran dalam profesion perguruan. Maka dengan ini profesion perguruan akan dihormati dan disanjung tinggi oleh masyarakat.

\subsection{PENUTUP}

Kajian ini adalah bertujuan untuk mengkaji faktor-faktor yang mempengaruhi pemilihan profesion perguruan dan kaitan dengan tahun pengajian pelajar yang mengambil kursus pendidikan di Fakulti Pendidikan, Universiti Teknologi Malaysia Skudai. Dapatan ini dapat memberi manfaat kepada pihak Fakulti Pendidikan agar dapat membaiki kekurangan yang terdapat daripada produk yang dihasilkan, iaitu bakal-bakal guru apabila keluar dari institusi ini. Dapatan kajian ini juga dapat dimanfaatkan oleh pensyarah supaya mengaitkan pelajaran yang diajar dengan pekerjaan yang bakal dilakukan oleh pelajar mereka. Kajian ini juga amat berguna kepada pelajar-pelajar yang mengambil kursus pendidikan untuk menilai faktorfaktor yang harus di ambil berat untuk memilih sesuatu profesion. Segala cadangan yang diutarakan adalah suatu pandangan untuk meningkatkan pengetahuan tentang faktor-faktor pemilihan profesion perguruan. 


\section{REFERENCES}

Atan Long. 1984. Pendidik dan Pendidikan. Petaling Jaya: Fajar Bakti.

Awang Had Salleh. 1980. Pendidikan ke Arah Perpaduan. Kuala Lumpur: Fajar Bakti Sdn Bhd.

Brody and Stone. 1981. Human Mental and Emotional Development. New Jersey: Prentice Hall.

Burner, B. 1960. Managing Change: A Strategic Approach the Organizational Dynamics. $2^{\text {nd }}$ Ed. London: Pitman.

Crites, J. 1969. Vocational Psycology the Study of Vocational Behavior and Development. London: Mc Craw Hill Book Company.

Crow and Crow. 1981. Psikologi Pendidikan untuk Perguruan. Kuala Lumpur: Dewan Bahasa dan Pustaka.

Ee Ah Meng. 1974. Sambutan di Kalangan Masyarakat Tempatan terhadap Profesion Guru. Universiti Pertanian Malaysia: Latihan Ilmiah Ijazah Sarjana Muda Sastera.

Esah Sulaiman. 2002. Profesionalisme Pendidikan. Universiti Teknologi Malaysia.

Garrison, K. C. 1965. Psychology of Adolescence. New York: Engle Wood Cliffs, (S.I).

Ginzberg, E. 1951. Occupational Choice, an Approach to a General Theory. New York: Colombia University Press.

Gobi. 1997. Persepsi Masyarakat India terhadap Profesion Perguruan: Satu Tinjauan di Kawasan Skudai, Johor Bahru. Universiti Teknologi Malaysia: Tesis Sarjana Muda.

Goodlad, J. I. 1984. A Place Called School: Prospect for the Future. New York: McGraw Hill.

Happock, R. 1976. Occupational Information. USA: McGraw Hill.

Holland, J. L. 1973. Making Vocational Choice: A Theory of Careers. Printice Hall: New Jersey. 3(1): 69-83.

Ismail Haji Reduan. 1992. Faktor-faktor yang Mempengaruhi Kejayaan Pengajaran dan Pembelajaran Matematik di Kalangan Murid Sekolah Rendah. Jurnal Akademik MPKT. Kuala Terengganu. 137-147.

Khashiatul-Fauziah Binti Hamzah. 2003. Faktor-faktor yang Mempengaruhi Pemilihan Kerjaya di Kalangan Remaja Melayu di Daerah Batu Pahat. Universiti Teknologi Malaysia, Projek Sarjana Muda.

Kider. 1990. A Theory Vocational Development. American Psychologists. 8: 185-190.

Mingguan Malaysia. Dicubit Guru 110 Kali. (27 Februari 2005).

Mohd Fadilah Khamsah. 1995. Menilai Semula Profesion Perguruan. Mestika, Mei.

Mohd Majid Konting. 1998. Kaedah Penyelidikan Pendidikan. Kuala Lumpur: Dewan Bahasa dan Pustaka.

Mohd Najib Ghafar. 1999. Penyelidikan Pendidikan. Universiti Teknologi Malaysia: Cetak Ratu Sdn. Bhd.

Mohamad Najib Abdul Ghafar. 2003. Reka Bentuk Tinjauan Soal Selidik Pendidikan. Universiti Teknologi Malaysia: Umida Industries Sdn. Bhd.

Mok Song Sang. 1995. Matematik untuk Dinamika Guru. Kuala Lumpur: Kumpulan Budiman.

Muhibbin Syah. 1995. Minat dan Proses Perkembangan Kerjaya. Buletin Melewar. Bil 1 (Julai-Disember).

Noran Fauziah Yaakub dan Ahmad Mahdzan Ayob. 1990. Guru dan Perguruan. Kuala Lumpur: Dewan Bahasa dan Pustaka.

Noran Fauziah Yaakup dan Ahmad Mahdzan Ayob. 1993. Guru dan Perguruan. Cetakan Ketiga. Kuala Lumpur: Kementerian Pendidikan Malaysia, Dewan Bahasa dan Pustaka.

Noran Fauziah Yaakub. 1988. The Relationship Between Personaliti Traits, Motives for Teaching and Teacher Trainee Attitude Toward Teaching and Their Performance. Universiti Kebangsaan Malaysia: Tesis Ph.D.

Norlia Melawi. 2000. Faktor-Faktor yang Mempengaruhi Pelajar Tahun Satu, Fakulti Pendidikan, Universiti Teknologi Malaysia Memilih Kerjaya Perguruan, Satu Tinjauan Awal. Universiti Teknologi Malaysia: Tesis Sarjana Muda.

Shasha Azman. 2004. Pengorbanan Guru dan Realiti Dunia Pendidikan. Dewan Masyarakat. Januari, M/S9;15:18

Tajul Ariffin dan Nor Aini Dan. 1992. Pendidikan dan Wawasan 2020. Kuala Lumpur: Dewan Bahasa dan Pustaka.

Tuckman, W. B. 1944. Motives for Choice of Teaching by Training College Students. British Journal of Education Psychology. 14: 129-141.

Shockley, R. J. and G. W. Cutlip. 1997. Careers in Teaching. New York: Rosen Publishing Group.

Sufean Hussin. 1993. Pendidikan di Malaysia: Sejarah, Sistem dan Falsafah. Kuala Lumpur: Dewan Bahasa dan Pustaka.

Walker, N. E. 1990. Teachers for Tommorow. Educational Research. 19(3): 184-191.

Zainun. 1994. Profesion Guru dan Cabaran. Mestika, November. 